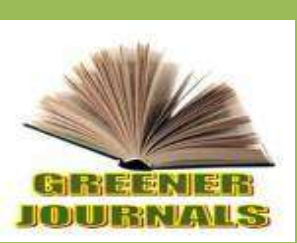

\title{
Nutritive Value of three varieties of banana and plantain blossoms from Cameroon
}

\section{Awedem Wobiwo Florenta ${ }^{a}$, Achu Mercy Bih Loha ${ }^{b}$ and Happi Emaga Thomas ${ }^{\text {bc* }}$}

\author{
aLaboratory for Food Science and Metabolism, Department of Biochemistry, University of \\ Yaoundé I, P. O. Box 812 Yaoundé, Cameroon. \\ ${ }^{\mathrm{b}}$ Post harvest Technology Laboratory, African Research Centre on Bananas and Plantains \\ (CARBAP), Njombé, P. O. Box 832 Douala, Cameroon. \\ ${ }^{\mathrm{C}}$ Gembloux Agro-Bio Tech, Department of Industrial Biological Chemistry, Passage des \\ Déportés, 2, B-5030 Gembloux, Belgium.
}

Article No.: 012115009

DOI: $10.15580 / G J A S .2015 .2 .012115009$

Submitted: $12 / 11 / 2014$

Accepted: $21 / 01 / 2015$

Published: 05/02/2015

\section{*Corresponding Author}

Happi Emaga Thomas

E-mail: guythappi@yahoo.fr

Phone: 0023799471995

\section{Keywords:}

banana and plantain blossoms, nutritive value, varieties
Background: The by-products of banana and plantain shrubs, especially banana blossom (banana male bud) are usually thrown away by producers in plantations, and produce important quantities of post harvest waste. The nutritional composition of three varieties of banana and plantain blossoms grown in Cameroon; dessert banana (Musa AAA), plantain (Musa AAB) and cooking banana (Musa ABB), was assessed for their potential applications.

Methods: The contents in water, ash, lipids, protids, carbohydrates and crude fibres were determined using standard A.O.A.C methods. The sugar levels were assayed using colorimetric methods, dietary fibres by enzymatic digestion, amino acids by HPLC, fatty acids by gas chromatography and minerals by atomic absorption spectrophotometry.

Results: The results showed that the water content varies from 92.29 (AAA) to $93.73 \%$ F.W. (AAB). The ash content varies from 9.88 (AAB) to $12.25 \%$ D.W. (AAA). The lipid content varies from 4.95 (AAA) to $15.69 \%$ D.W. (ABB) and contains polyunsaturated fatty acids (33.80 - $41.50 \mathrm{~g} / 100 \mathrm{~g} \mathrm{FM}$ ), particularly linoleic and gamma linolenic acids. The total protein content varies from 8.89 (AAB) to $10.35 \%$ D.W. (AAA). Leucine, phenylalanine + tyrosine, valine, lysine and threonine are the main essential amino acids $(2.75-3.30 \%)$. The total carbohydrate content varies from 22.36 (AAA) to $62.19 \%$ D.W. (AAB) and glucose, fructose and sucrose are dominant in the AAB genotype with values of $(8.15 ; 3.04$ and $1.35 \%$ respectively). The AAA genotype is rich in total dietary fibres $(50.09 \%)$. These banana and plantain flowers are rich in macrominerals. Potassium, calcium, magnesium and phosphorus levels are high in the AAA genotype, with values of $(6480 ; 687 ; 273 ; 211$ $\mathrm{mg} / 100 \mathrm{~g}$ D.W., respectively).

Conclusions: These blossoms could be considered as a source of dietary fibres for the control of obesity and diabetes.Further investigations on the composition and the physiological functions (using animal-feeding experiments) of these dietary fibres are to be considered. 


\title{
LIST OF ABBREVIATIONS
}

\author{
AOAC: Association of Official Analytical Chemists \\ FM: Fat Matter \\ FW: Fresh Weight \\ DW.: Dry Weight \\ CARBAP: Centre Africain de Recherches sur Bananiers et Plantains \\ g: gramme \\ $\mathrm{mg}$ : milligramme
}

\section{INTRODUCTION}

Banana and plantain plants are the world's biggest herbs, grown abundantly in many developing countries. Bananas and plantains are one of the most important sources of energy in the diet of people living in tropical humid regions. The plants are stenothermic, cultivated in hot and wet regions, and bear fruits all year round. There are approximately 1200 varieties of bananas all over the world (Kouassi, 2001). Banana is a general term embracing a number of species or hybrids in the genus Musa of the family Musaceae. Almost all of the known edible-fruit cultivars arose from two diploid species, Musa acuminata (AA) and Musa balbisiana (BB). Moreover, there are diploid, triploid and tetraploid hybrids made up of subspecies of $M$. acuminata, and subspecies between $M$. acuminata and M. balbisiana (Stover and Simmonds, 1987; Robinso, 1996). Dessert bananas for world food trade are almost entirely derived from genetic make ups of Musa acuminata of triploid character, indicated as AAA. Plantain (Musa AAB) and other bananas that can be used for cooking (cooking bananas, Musa ABB) are also triploid and derived from the AA.BB hybridization. Plantains and cooking bananas are very similar to unripe dessert bananas in outward appearance, although often larger. The major differences are that their flesh is starchy rather than sweet, they are used unripe, and require cooking. Bananas and plantains constitute the principal food resources in the world. They occupy the Fourth place in the World's most significant foodstuffs after rice, corn and milk (FAO, 1999; INIBAP, 2002). Banana trees are produced in large quantities in tropical and subtropical areas. In Africa, the main producers are Uganda and Cameroon. In Cameroon, the production of bananas and plantains represents the second agricultural economic resource of the country after wood (FAO, 2001). These bananas and plantains are the third most consumed food (Dury et al., 2002) and since 2007 the exportation of bananas and plantains has tripled in Cameroon (Lassoudière, 2007). However, each time one banana stem is produced; one banana blossom is also produced because it is usually harvested together with the banana. These banana blossoms are usually thrown away by producers in plantations and are one of the agricultural by-products which are getting more attention from many researchers and food manufacturers as potentially, a food source. Byproducts of vegetables and plants are usually discarded post-harvesting or processing, as it was not always needed in the production of food. Although few studies covering all aspects of chemistry by-products of banana have been reported in the literature, recent works has been done on some of these by-products, namely banana peel and have shown that these banana peels are rich in unsaturated fatty acids, antioxidants and good quality protein (Happi Emaga et al., 2007). These peels are also rich in starch (35.4 $39.3 \%$ DW); they are a source of pectin and dietary fibres (40-50\% DW), especially insoluble dietary fibres (Happi Emaga et al., 2008a). In the same way, the characterization of pectins from these banana peels show that they can be used as a therapeutic molecule for diabetes and cardiovascular disease in the sense that pectins reduce blood sugar and cholesterol levels in the blood ( Happi Emaga et al., 2008b). However, since there are several recent studies that have reported on food production using these by-products and indicating they can improve the nutritional value, especially the dietary fibre level of the food produced (Wickramarachchi and Ranamukhaarachchi, 2005). Bananas flowers are large, dark purple-red blossoms that grow from the end of a bunch of bananas. They are also called banana inflorescence, banana blossom or banana male bud. They are an agricultural byproduct that is often consumed as vegetable in many Asian countries such Malaysia, Indonesia, Sri Lanka, Philippines and other South-East Asian countries (Wickramarachchi and Ranamukhaarachchi, 2005). Despite the fact that they are generally consumed as vegetable, only a few studies have been carried out on their nutritional value and dietary fibre content. There is little mention of their use in literature. Potential applications of these banana blossoms depend on their nutritional composition. However, some papers have dealed with their different therapeutic applications such as the prevention of intestinal cancer (Pari and Maheshwari, 2000; Wickramarachchi and Ranamukhaarachchi, 2005), the treatment of hyperglycemia and type II diabetes through the activation of GLU T1 and T4 carriers (Pasupuleti and Anderson, 2008; Bhaskar et al., 2011). For these reasons, the present research is to bring out other applications for these by-products, in order to make them more useful to farmers of this sector, by determining a detailed nutritional composition of banana and plantain blossoms grown in Cameroon.

\section{MATERIALS AND METHODS}

\section{Sample preparation}


The bananas and plantain blossoms (photo 1) used in this study were from three varieties of bananas trees. All the varieties were obtained from the African Research Centre on Bananas and Plantains (CARBAP), Cameroon: namely Lagun Vunalir of AAA genotype (dessert banana), Zip Ekon of AAB genotype (plantain), and Pisang Kepok Bung of ABB genotype (cooking banana). The choice of each variety was done on those which were not used or found in literature. The banana blossoms were washed and separated into particles. They were dried at $55^{\circ} \mathrm{C}$ for $48 \mathrm{~h}$, and then stored in polypropylene bags in the desiccators before use.

\section{Chemical analysis}

The water content and the ash content of the banana blossoms were estimated according to standard methods (AOAC, 1980). Total lipids were extracted by continuous reflux in a Soxhlet apparatus (Soxtherm S306 AK Automatic Extractor System branstead electrothermal Gerhardt, Germany) for 8 h, using hexane (boiling range: $60-80^{\circ} \mathrm{C}$ ). The extracted lipids were heated in an oven at $70^{\circ} \mathrm{C}$ for $1 \mathrm{~h}$ to remove all traces of solvent. The total nitrogen content $(\mathrm{N})$ was determined using the standard Kjeldahl procedure (AOAC, 1980), by nitrogen determination after digestion (with a 1000 Kjeltabs MQ tablet and a Digestion System 20, 1015 Digester, Tecator, AB, Höganäs Sweden) and distillation ( using a Kjeltec Auto 1030 Analyser, Tecator, AB, Höganäs, Sweden). Crude protein was expressed as $6.25 \times \mathrm{N}$. The mineral content (concentrations of sodium, potassium, calcium, magnesium, zinc, iron, copper and manganese) were determined using a flame atomic absorption spectrophotometer (Perkin-Elmer, 2380) according to the Benton and Vernon method (Benton and Vernon, 1990). For the phosphorus content, the Murphy Riley reagent method was used (Murphy and Riley, 1962). Total amino acids composition of the banana and plantain blossoms was obtained after hydrolysis under nitrogen with $6 \mathrm{~N} \mathrm{HCl}$ at $110^{\circ} \mathrm{C}$ for $24 \mathrm{~h}$ (Kaiser et al., 1974) and analyses of the amino acids was done by High Performance Liquid Chromatography, HPLC (Stein and Moore, Biochrom 20 Plus, Pharmacia, Cambridge, UK). Norleucine (500 nM) was added as internal standard. The hydrolysates were injected into a cation-exchange column and the amino acids were separated by elution with suitable buffers of increasing $\mathrm{pH}$, and detected with ninhydrin in a continuous flow photometric analytical system at $570 \mathrm{~nm}$ and at $440 \mathrm{~nm}$
( for proline) and quantified by Sigma calibration standards. Sulphur amino acids (cysteine and methionine) were determined as cysteic acid and methionine sulphone, respectively using an amino acid analyser (Biochrom 20 Plus, Pharmacia, Cambridge, UK). The protein quality of the samples was evaluated using the relationship between total essential amino acids and total non essential amino acids. The Fatty acid composition was determined by gas liquid chromatography (GLC), according to IUPAC Method (IUPAC, 1990). This was done using a HewlettPackard 6890 series Gas Chromatograph System equipped with a HP-INNOWAX capillary column $(30 \mathrm{~m}$ $x 0.25 \mathrm{~mm}$, film thickness $0.32 \mu \mathrm{l})$. Derived extracts $(1.0 \mu \mathrm{l})$ in hexane were injected into the column. The oven temperature was programmed from 50 (isothermal for $1 \mathrm{~min}$ ) to $150^{\circ} \mathrm{C}$ at $30^{\circ} \mathrm{C} / \mathrm{min}$ and from $150^{\circ} \mathrm{C}$ to $240^{\circ} \mathrm{C}$ (isothermal for $10 \mathrm{~min}$ ) at $4^{\circ} \mathrm{C} / \mathrm{min}$. Compounds were detected using a flame ionisation detector at $325 \mathrm{~nm}$. Helium was used as carrier gas at a flow rate of $65 \mathrm{ml} / \mathrm{min}$. Identification and quantification of fatty acid methyl esters was done by comparing the retention times of the peaks with those of standards of Supelco 37 component FAME Mix $1 \mathrm{ml}$ (Supelco Inc., Bellefonte, PA, USA). Soluble dietary fibre (SDF) and insoluble dietary fibres (IDF) were analysed according to AOAC methods (Prosky et al., (1992). Total dietary fibre (TDF) was calculated as IDF plus soluble dietary fibre (SDF) (Prosky et al., (1992). Briefly, the samples were suspended in buffer, sequentially digested by heat-stable alpha-amylase, protease and amyloglucosidase to remove starch and protein. IDF was recovered from the enzyme digest after filtration. SDF in the filtrate was precipitated with ethanol and filtered. All dietary fibre (DF) fractions collected were dried. These DF contents were corrected for residual protein, ash, and blank. Soluble sugars (glucose, fructose and sucrose) were quantified according to the colorimetric method of Dubois et al. (1956). Sucrose, fructose and glucose standards were used for quantification. For these, the samples were homogenized with water for $1 \mathrm{~h}$ at $35^{\circ} \mathrm{C}$. The extract was filtered through $0.45 \mu \mathrm{m}$ Millipore filters and the absorbance was read at $490 \mathrm{~nm}$ using a spectrophotometer (Thermo Scientific 205). All the analyses were done in triplicate and the data obtained were statistically analysed with IBM SPSS software 20.0 for Windows. One-way Analysis of Variance (ANOVA) test and the Least Significant Difference (LSD) at the critical point $5 \%$ was done to compared the different value. 


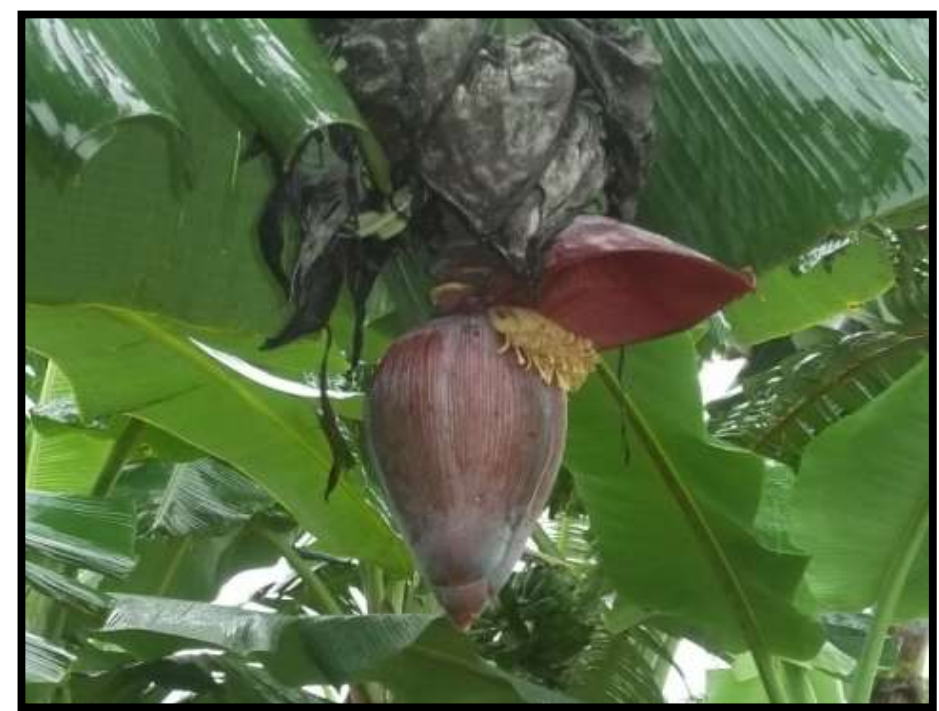

Photo 1: banana blossom

\section{RESULTS AND DISCUSSION}

\section{Proximate composition}

Table 1: Proximate composition (\% dry weight, DW)

\begin{tabular}{|l|l|c|l|l|}
\hline \hline Genotype & \multicolumn{3}{|c|}{ Nutrients } \\
\cline { 2 - 5 } & \hline Water & Ash & Lipids & Proteins \\
\hline AAA & $92.29 \pm 0.45^{\mathrm{c}}$ & $12.25 \pm 0.14^{\mathrm{a}}$ & $4.95 \pm 0.11^{\mathrm{c}}$ & $10.35 \pm 0.50^{\mathrm{a}}$ \\
AAB & $93.73 \pm 0.55^{\mathrm{a}}$ & $9.88 \pm 0.34^{\mathrm{b}}$ & $8.81 \pm 0.28^{\mathrm{b}}$ & $8.89 \pm 0.66^{\mathrm{c}}$ \\
ABB & $92.88 \pm 0.32^{\mathrm{ac}}$ & $10.08 \pm 0.20^{\mathrm{b}}$ & $15.69 \pm 0.38^{\mathrm{a}}$ & $10.06 \pm 0.43^{\mathrm{ac}}$ \\
\hline
\end{tabular}

NB: Means with different letter superscripts on the same column are statistically different $(P<0.05)$.

The proximate composition of banana blossoms is showed on Table 1. The water content of the banana blossoms of AAA (Lagun Vunalir), AAB (Zip Ekon) and ABB genotypes (Pisang Kepok Bung) are 92.29, 93.73 and $92.88 \%$ respectively. There is a significant difference $(p<0.05)$ between the values of $A A A$ and $A A B$ genotypes. The water content of $A A A$ and $A A B$ is higher than that of AAA (90.58\%) and AAB (89.42 $\%)$ ) obtained by Sheng et al., (2010) (variety not specified). On the other hand, the water content of the banana blossoms of ABB genotype is similar to that (92 \%) obtained by Wickramarachchi and Ranamukhaarachchi, (2005). The water content of food is of great importance in Food Technology, for it makes possible to estimate its lifespan and its mode of preservation.

The ash content of the banana blossoms of AAA (Lagun Vunalir), $A A B$ (Zip Ekon) and ABB genotype (Pisang Kepok Bung) are $12.25 \%$, $9.88 \%$ and $10.08 \%$ respectively (Table 1$)$. These values represent the percentage of the mineral fraction in food. There is a significant difference $(p<0.05)$ between these values and they depend on the genotypes. The $A A A$ and $A A B$ genotype values are higher than those of AAA (1.19\%) and AAB (1.2\%) obtained by Sheng et al., (2010). The value of ABB genotype is slightly higher than that $(8.53 \%)$ obtained by Wickramarachchi and Ranamukhaarachchi, (2005) for the same genotype. However, the value obtained for $A A B$ is similar to that (10\%) observed by Akubor and Ishiwu, (2013), while the value obtained for AAA is much higher than that $(0.5 \%)$ obtained by Bhaskar et al., (2012). These differences could be due to the difference in chemical composition of the various genotypes and also due to the difference zones of cultivation.

The lipids contents of the banana blossoms of the AAA (Lagun Vunalir), AAB (Zip Ekon) and ABB genotype (Pisang Kepok Bung) are $4.95 \%, 8.81 \%$ and $15.69 \%$ respectively (Table 1 ). The difference is significant $(p<0.05)$ between these values and they depend on the genotypes. The value obtained for AAA is much higher than that $(0.4 \%)$ obtained by Sheng et al., (2010), but lower than (12.7\%) obtained by 
Bhaskar et al., (2012). Also, the value obtained for AAB is higher than $(0.6 \%)$ that obtained by Sheng et al., (2010) and that $(4.8 \%)$ obtained by Akubor and Ishiwu, (2013). These also, could be due to differences in the zones of cultivation of these various genotypes, the varietal difference within the same genomic group and the influence of the levels of other macronutrients. In the human organism, lipids have different functions according to their nature and their distribution; hence they can act as energy stores or have a structural role (AFSSA, 2009). However, the lipid content of these samples increases with the letter $B$ of the various genotypes. This could mean that the Musa balbisiana (BB) may be richer in lipids than the Genus, Musa accuminata (AA). The protein contents of the banana blossoms AAA (Lagun Vunalir), AAB (Zip Ekon) and ABB genotype (Pisang Kepok Bung) are 10.358 .89 and $10.06 \%$ respectively (Table 1 ). There is a significant difference $(p<0.05)$ between the values of $A A A$ and $A A B$ genotype while that of $A B B$ genotype is similar to these two genotypes. The protein content of the AAA genotype is higher than that (2.07\%) obtained by Sheng et al., (2010) for AAA genotype. On the other hand, it is slightly lower than that (12.5\%) obtained by Bhaskar et al., (2012) for the same genotype. This reveals that in the same genomic group, the protein content can vary according to the various sub-groups of cultivated triploid banana trees. The genomic protein contents of $A A B$ and $A B B$ groups are respectively higher and lower than those obtained ( $6 \%$ for $A A B$ and $20.54 \%$ for ABB) by Sheng et al., (2010) and Wickramarachchi and Ranamukhaarachchi, (2005). In the same way, the value obtained for $A A B$ genotype is slightly higher than that $(7 \%)$ found by Akubor and Ishiwu, (2013). These differences could be explained by the fact that the protein contents depend on the various genomic groups. However, the values obtained (10\%) showed that the banana blossoms of the banana tree of AAA and $A B B$ genotypes can be regarded as source of proteins (FAO, 1970).

\section{Total carbohydrates and soluble sugars}

The average contents of total carbohydrates, sucrose, glucose and fructose of the banana blossoms are given on Table 2.

Table 2: Total carbohydrates and sugar contents (\% dry weight, DW)

\begin{tabular}{|l|l|l|l|l|}
\hline \hline Genotype & \multicolumn{3}{|c|}{ Sugar constituent } \\
\cline { 2 - 5 } & \hline Total Carbohydrates & Sucrose & Glucose & Fructose \\
\hline AAA & $22.36 \pm 0.52^{\mathrm{c}}$ & $0.73 \pm 0.33^{\mathrm{ac}}$ & $6.53 \pm 0.15^{\mathrm{b}}$ & $2.20 \pm 0.45^{\mathrm{ac}}$ \\
$\mathrm{AAB}$ & $62.19 \pm 0.50^{\mathrm{a}}$ & $1.35 \pm 0.33^{\mathrm{a}}$ & $8.15 \pm 0.17^{\mathrm{a}}$ & $3.04 \pm 0.45^{\mathrm{a}}$ \\
ABB & $45.73 \pm 0.46^{\mathrm{b}}$ & $0.03 \pm 0.21^{\mathrm{c}}$ & $3.81 \pm 0.02^{\mathrm{c}}$ & $1.24 \pm 0.29^{\mathrm{c}}$ \\
\hline \hline
\end{tabular}

NB: Means with different letter superscripts on the same column are statistically different $(P<0.05)$.

The total carbohydrate contents vary from 22.36 (AAA) to $62.19 \%(A A B)$ and present a significant difference $(p<0.05)$ between the various genotypes. The values obtained for $A A A$ and $A A B$ genotypes are lower than those $(90.80 \%$ for AAA (Baxijiao) and $90.00 \%$ for AAB (Paradisiaca) observed by Sheng et al., (2010). This difference could be explained not only by varietal diversification within the same genomic group, but also by the difference in the various zones of cultivation. The total carbohydrate contents of $A A B$ and $A B B$ genomic groups are higher than those obtained for banana skins (40\% and $29 \%$ respectively) by Mohapatra et al., (2010) in India. The value obtained for AAB genotype is similar to that $(62.2 \%)$ observed by Akubor and Ishiwu, (2013). However, the results obtained show that the banana blossoms can be a source of carbohydrates (FAO, 1970).

The sucrose content varies from 0.03 (ABB) to $1.35 \%$ (AAB) (Table 2) and show a significant difference $(p<0.05)$ between the various genotypes. The values obtained are lower than those $(1.5,0.2$ and $0.4 \%$ respectively) of the banana peels of AAA (Large
Dwarf), $A A B$ (French Clair) and $A B B$ genotype (pelipita) by Happi Emaga et al., (2007). This shows that peels of $A A A$ and $A B B$ genotype are richer in sucrose than the banana blossoms of the of the same banana tree genotype. On the other hand, the banana blossoms of $A A B$ genotype have more sucrose than its peels. The values obtained show that the male buds of $A A A$ and $A A B$ genotypes can be regarded as source of sucrose (FAO, 1970).

The glucose content of the banana blossoms of AAA (Lagun Vunalir), $A A B$ (Zip Ekon) and ABB genotype (Pisang Kepok Bung) are 6.53, 8.15 and $3.81 \%$ respectively (Table 2 ). There is a significant difference $(p<0.05)$ between these values, and they depend on the genomic groups. These values are higher than those $(2 \%, 1 \%$ and $0.4 \%)$ of the banana peels of genomic groups, AAA (Large Dwarf), AAB (Big Ebanga) and ABB (pelipita) respectively (Happi Emaga et al., 2007). The results obtained suggest that even within the same genomic group, the glucose level can vary with the various varieties. However, glucose is required by several cells for their survival, the 
reactions of energy production in the form of ATP as well as the synthesis of various macromolecules containing this sugar (Bhaskar et al., 2011).

The fructose contents of the banana blossoms of AAA (Lagun Vunalir, $2.20 \%$ ), AAB (Zip Ekon, $3.04 \%$ ) and ABB genotype (Pisang Kepok Bung, 1.24 $\%)$ are reported on Table 2. There is a significant difference $(p<0.05)$ between these values and they depend on the genotype. These values are higher than those $(1.2 \%, 2.2 \%$ and $0.1 \%)$ of the banana peels of AAA (Large Dwarf), AAB (Big Ebanga) and ABB (pelipita) genotype respectively (Happi Emaga et al., 2007). This suggests that the banana blossoms of $A A A, A A B$ and $A B B$ genotype contain more fructose than the banana peels of the same genotype. However, the glucose and fructose levels for AAA and $A A B$ genomic groups corroborate the hypothesis that the banana blossoms of these two genomic groups could be a source of simple sugars (Sheng et al., 2010).

\section{Amino acids composition}

The essential and non essential amino acids composition of the banana blossoms of the various genomic groups is given on Table 3 . This reveals that the banana blossoms of AAA (Lagun Vunalir), AAB (Zip Ekon) and ABB genotype (Pisang Kepok Bung) contain all the essential amino acids when referred to the classification of the FAO/WHO Committee (FAO/WHO, 2001). Tryptophan was destroyed during acid hydrolysis. The essential amino acid contents vary from $2.76 \%$ (AAA genotype) to $3.27 \%$ (ABB genotype) and present a significant difference $(p<0.05)$.

Table 3: Amino acid composition (\% dry weight, DW)

\begin{tabular}{|l|c|c|c|}
\hline \hline Amino acids & \multicolumn{3}{|c|}{ Genotypes } \\
& AAA & AAB & ABB \\
\hline Essential amino acids & $0.51 \pm 0.00^{\mathrm{c}}$ & $0.61 \pm 0.00^{\mathrm{b}}$ & $0.63 \pm 0.00^{\mathrm{a}}$ \\
Leucine & $0.44 \pm 0.00^{\mathrm{c}}$ & $0.49 \pm 0.00^{\mathrm{b}}$ & $0.52 \pm 0.01^{\mathrm{a}}$ \\
Valine & $0.36 \pm 0.00^{\mathrm{c}}$ & $0.38 \pm 0.00^{\mathrm{ac}}$ & $0.44 \pm 0.02^{\mathrm{a}}$ \\
Lysine & $0.33 \pm 0.00^{\mathrm{c}}$ & $0.38 \pm 0.00^{\mathrm{b}}$ & $0.40 \pm 0.00^{\mathrm{a}}$ \\
Threonine & $0.47 \pm 0.00^{\mathrm{c}}$ & $0.52 \pm 0.00^{\mathrm{b}}$ & $0.55 \pm 0.00^{\mathrm{a}}$ \\
Phénylalanine + Tyrosine & $0.29 \pm 0.00^{\mathrm{c}}$ & $0.35 \pm 0.00^{\mathrm{b}}$ & $0.37 \pm 0.00^{\mathrm{a}}$ \\
Isoleucine & $0.22 \pm 0.00^{\mathrm{a}}$ & $0.23 \pm 0.00^{\mathrm{a}}$ & $0.23 \pm 0.01^{\mathrm{a}}$ \\
Histidine & $0.14 \pm 0.02^{\mathrm{a}}$ & $0.12 \pm 0.00^{\mathrm{c}}$ & $0.13 \pm 0.00^{\mathrm{ac}}$ \\
Méthionine + Cystéine & 2.76 & 3.08 & 3.27 \\
$\sum_{1}$ & & & \\
Non essential amino acids & $1.19 \pm 0.01^{\mathrm{ac}}$ & $1.18 \pm 0.01^{\mathrm{c}}$ & $1.27 \pm 0.02^{\mathrm{a}}$ \\
Glutamate & $0.68 \pm 0.00^{\mathrm{c}}$ & $0.71 \pm 0.00^{\mathrm{ac}}$ & $0.72 \pm 0.01^{\mathrm{a}}$ \\
Aspartate & $0.40 \pm 0.00^{\mathrm{c}}$ & $0.43 \pm 0.00^{\mathrm{b}}$ & $0.45 \pm 0.00^{\mathrm{a}}$ \\
Serine & $0.36 \pm 0.00^{\mathrm{c}}$ & $0.41 \pm 0.00^{\mathrm{b}}$ & $0.45 \pm 0.00^{\mathrm{a}}$ \\
Alanine & $0.36 \pm 0.00^{\mathrm{c}}$ & $0.38 \pm 0.01^{\mathrm{ac}}$ & $0.40 \pm 0.00^{\mathrm{a}}$ \\
Arginine & $0.31 \pm 0.00^{\mathrm{c}}$ & $0.36 \pm 0.00^{\mathrm{a}}$ & $0.37 \pm 0.00^{\mathrm{a}}$ \\
Glycine & $0.26 \pm 0.01^{\mathrm{c}}$ & $0.30 \pm 0.00^{\mathrm{a}}$ & $0.31 \pm 0.00^{\mathrm{a}}$ \\
Proline & $0.03 \pm 0.00^{\mathrm{a}}$ & $0.03 \pm 0.00^{\mathrm{a}}$ & $0.03 \pm 0.00^{\mathrm{a}}$ \\
Cystine & 3.59 & 3.80 & 4.00 \\
$\sum_{2}=\sum_{1}+\sum_{2}$ & 6.35 & 6.88 & 7.27 \\
$\sum_{1} / \sum_{1}+\sum_{2}(\mathrm{~A})$ & 0.43 & 0.45 & 0.45 \\
\hline \hline
\end{tabular}

NB: Means with different letter superscripts on the same row are statistically different $(p<0.05)$.

$\Sigma 1=$ sum of the essential amino acids; $\Sigma 2=$ sum of the non essential amino acids; $A=\Sigma_{1} / \Sigma_{1}+\Sigma_{2}$.

The essential amino acid contents obtained are higher than those (1.7 - $2.6 \%$ ) observed by Happi Emaga et al., (2007) on the peels of the same banana genotype with different varieties. Hence, these values obtained corroborate those observed by Sheng et al., (2010), who noticed that banana blossoms contained all the essential amino acids. From Table 3, the amino acids, methionine + cysteine present the lowest content and so they are the limiting amino acids. Amongst the three genotypes, the ABB genotype (Pisang Kepok Bung) has the highest levels of essential amino acids and the dominating essential amino acid is leucine. The banana blossoms of AAA genotype have the lowest value $(0.43)$ of the ratio of the sum of essential amino acids to sum of total amino acids (A), while those of $A A B$ and $A B B$ genotypes present the highest value $(0.45)$. This ratio $(A)$ shows that the banana blossoms of $A A B$ and $A B B$ genotypes have a high percentage of essential amino acids than those of AAA genotype. However, FAO/WHO ( $\mathrm{FAO} / \mathrm{WHO}, 2007$ ) recommend on average, 1.2 to 2.3 $\% / \mathrm{Kg} /$ day contribution in essential amino acids in children from 6 to 12 months. This suggests that the powders of these banana blossoms could be introduced like food supplements into the pap of these children in order to enrich their feeding. 
The non essential amino acid contents vary from 3.59 (AAA) to $4.00 \%$ (ABB genotype) and present a significant difference $(p<0.05)$ between these values. The contents observed are respectively higher and lower than those $(2.7 \%$ for AAA and $5.5 \%$ for ABB) observed by Happi Emaga et al., (2007) in the banana peels of the same genotype with different varieties. As observed by this last author, the ABB genotype shows the highest value of non essential amino acids. However, the quantity of protein was much higher than the sum of the amino acids. This could be explained by the fact that the Kjeldahl method used here, determines all $\mathrm{N}$ compounds, not only proteins or amino acids, which leads to an over estimation of the protein content. There exist other $\mathrm{N}$ compounds than protein. (Kanazawa and Sakakibara (2000); Someya et al., (2002)) have for example, shown that banana by-products contain large quantities of antioxidants ( $1 \% \mathrm{DM})$, e.g. dopamine.

\section{Fatty acid Composition}

The fatty acid composition of the oils extracted from the banana blossoms expressed as a percentage of the fatty matter (FM) is reported on Table 4. This reveals that the saturated fatty acid contents of AAA (Lagun Vunalir), AAB (Zip Ekon) and ABB genotype (Pisang Kepok Bung) are $57.92 \%, 53.31 \%$ and 57.17 $\%$ respectively. There is a significant difference $(p<0.05)$ between these values, and the genotype AAA is dominating. Among the saturated fatty acids obtained, palmitic acid is the most abundant, followed by stearic, behenic, lignoceric and arachidic acids in smaller quantities. The values of saturated fatty acids obtained for the three genotypes are higher than those (51.9, 46.6 and $41.1 \%$ ) observed by Happi Emaga et al., (2007) for the banana peels of AAA (Large Dwarf), $A A B$ (Big Ebanga) and ABB (pelipita) respectively, collected from the same area of cultivation (CARBAP).This observation shows the difference in chemical composition between byproducts of the banana trees of the same genotype, and confirms the varietal difference within the same genomic group.

Table 4: Fatty acid composition (g/100g FM)

\begin{tabular}{|l|c|c|c|}
\hline \hline Fatty acid & \multicolumn{3}{|c|}{ Genotype } \\
\cline { 2 - 4 } & AAA & AAB & ABB \\
\hline Myristic acid (C14:0) & $0.00 \pm 0.00^{\mathrm{a}}$ & $0.23 \pm 0.00^{\mathrm{a}}$ & $0.00 \pm 0.00^{\mathrm{a}}$ \\
Pentadeconoic acid (C15:0) & $0.00 \pm 0.00^{\mathrm{a}}$ & $0.90 \pm 0.00^{\mathrm{a}}$ & $0.00 \pm 0.00^{\mathrm{a}}$ \\
Palmitic acid (C16:0) & $36.93 \pm 0.16^{\mathrm{c}}$ & $34.97 \pm 0.23^{\mathrm{b}}$ & $41.93 \pm 0.63^{\mathrm{a}}$ \\
Stearic acid (C18:0) & $9.73 \pm 0.03^{\mathrm{a}}$ & $5.17 \pm 0.03^{\mathrm{b}}$ & $4.47 \pm 0.03^{\mathrm{c}}$ \\
Arachidic acid (C20:0) & $2.20 \pm 0.00^{\mathrm{b}}$ & $2.17 \pm 0.03^{\mathrm{b}}$ & $2.67 \pm 0.03^{\mathrm{a}}$ \\
Behenic acid (C22:0) & $5.30 \pm 0.00^{\mathrm{b}}$ & $5.57 \pm 0.03^{\mathrm{a}}$ & $4.00 \pm 0.10^{\mathrm{c}}$ \\
Lignoceric acid (C24:0) & $3.76 \pm 0.36^{\mathrm{a}}$ & $4.30 \pm 0.00^{\mathrm{a}}$ & $4.10 \pm 0.20^{\mathrm{a}}$ \\
\% Saturated fatty acids & 57.92 & 53.31 & 57.17 \\
Myristoleic acid (14:1) & $0.00 \pm 0.00^{\mathrm{a}}$ & $0.67 \pm 0.33^{\mathrm{a}}$ & $1.20 \pm 0.60^{\mathrm{a}}$ \\
Oleic acid (18:1) & $8.63 \pm 0.06^{\mathrm{a}}$ & $4.77 \pm 0.03^{\mathrm{b}}$ & $6.80 \pm 0.10^{\mathrm{c}}$ \\
\% Monounsaturated fatty acids & 8.63 & 5.44 & 8.00 \\
Linoleic acid (C18:2) & $28.17 \pm 0.13^{\mathrm{b}}$ & $32.30 \pm 0.20^{\mathrm{a}}$ & $29.13 \pm 0.36^{\mathrm{b}}$ \\
Gamma linolenic acid (C18:3) & $5.63 \pm 0.06^{\mathrm{c}}$ & $9.20 \pm 0.00^{\mathrm{a}}$ & $6.60 \pm 0.10^{\mathrm{b}}$ \\
\% Polyunsaturated fatty acids & 33.80 & 41.50 & 35.73 \\
\hline \hline
\end{tabular}

NB: Means with a different letter superscripts on the same row are statistically different $(p<0.05)$.

The monounsaturated fatty acid contents of the banana blossoms vary from 5.44 (AAB) to $8.63 \%$ (AAA genotype) and mainly consists of oleic acid. As observed with the saturated fatty acids, the monounsaturated fatty acid levels are also higher than those $(4.2 \%$ for $A A A, 4.1 \%$ for $A A B$ and $4.6 \%$ for ABB) obtained for banana peels by Happi Emaga et al., (2007). Oleic acid is an energy reserve for fats in a semi-fluid state. It is also a precursor of polyunsaturated fatty acids under the action of the desaturases (AFSSA, 2009). The polyunsaturated fatty acid contents of the banana blossoms of AAA (Lagun Vunalir), AAB (Zip Ekon) and ABB genotype (Pisang Kepok Bung) are 33.80, 41.50 and $35.73 \%$ respectively (Table 4$)$. There is a significant difference $(p<0.05)$ between these values and AAB has the highest value. The polyunsaturated fatty acids obtained from the extracted oils are n-6 (omega-6) series and especially linoleic acid. The linoleic acid values obtained for the three genotypes are higher than those $(22.7 \%, 23.9 \%$ and $22.5 \%)$ observed by Happi Emaga et al., (2007) for banana peels of AAA (Large Dwarf), $A A B$ (Big Ebanga) and ABB (pelipita) genotype respectively, collected from the same area of cultivation (CARBAP). Linoleic acid is an essential fatty acid which cannot be synthesized in the organism. It can only be got from food. Its metabolism generally leads to cellular differentiation and production of hormones such as prostaglandin, which is a reproductive hormone (Ramadan and Mörsel, 2002). The FAO/WHO (2003) recommends an intake of $3-4.5 \% /$ day of polyunsaturated fatty acids (omega-6) in children of 6 to 12 months. This suggests that the powders of these blossoms could be introduced like food supplements into the food of these children for a better balanced diet. However, polyunsaturated fatty acids are very important in food because of their roles in nervous, retinal and cerebral 
development, in the synthesis of biologically active molecules, the inflammatory process and in the genic regulation (Gil et al., 2012). They are involved in the mechanisms associated with protection against the ignition, the appearance of the metabolic syndrome and with the primary and secondary prevention of much degenerative and cardiovascular pathology (AFSSA, 2010).

\section{Dietary Fibre Composition}

Table 5: Dietary fibre composition (\% dry weight, DW)

\begin{tabular}{|l|c|c|c|}
\hline \hline Genotype & \multicolumn{3}{|c|}{ Dietary fibres } \\
\cline { 2 - 4 } & Insoluble dietary fibre (IDF) & Soluble dietary fibre (SDF) & Total dietary fibre (TDF) \\
\hline AAA & $45.28 \pm 0.31^{\mathrm{a}}$ & $4.80 \pm 0.58^{\mathrm{a}}$ & $50.09 \pm 1.34^{\mathrm{a}}$ \\
AAB & $9.40 \pm 0.42^{\mathrm{c}}$ & $0.82 \pm 0.06^{\mathrm{b}}$ & $10.23 \pm 0.72^{\mathrm{c}}$ \\
ABB & $16.94 \pm 0.45^{\mathrm{b}}$ & $1.54 \pm 0.09^{\mathrm{b}}$ & $18.44 \pm 0.81^{\mathrm{b}}$ \\
\hline \hline
\end{tabular}

NB: Means with different letter superscripts on the same column are statistically different $(P<0.05)$.

The total dietary fibre (TDF), insoluble dietary fibre (IDF) and soluble dietary fibre (SDF) contents are given on Table 5 . The composition of insoluble dietary fibre (IDF) of the banana blossoms of AAA (Lagun Vunalir), AAB (Zip Ekon) and ABB (Pisang Kepok Bung) genotype is respectively $45.28 \%, 9.40 \%$ and $16.94 \%$ (Table 5). There is a significant difference $(p<0.05)$ between these values, and genotype AAA is dominating. The content of insoluble dietary fibre of AAA genotype is lower than that $(58.3 \%)$ obtained by Bhaskar et al., (2012) on the same genotype (variety: Elakki Bale). The contents of IDF obtained for AAB and $A B B$ genotypes are lower than those $(29.7 \%$ and $29.2 \%$ ) observed in banana peels (Happi Emaga et al., 2007). These banana blossom fibres (IDF) might possibly have positive effects on intestinal regulation and stool volume, which are related to the consumption of insoluble fibre (Schneeman, 1987). The AAA genotype also had the highest SDF content $(4.80 \%)$ while $A A B$ and ABB genotype had a SDF content of $0.82 \%$ and $1.54 \%$ respectively (Table 5 ). The SDF content of AAA is lower than that $(7.3 \pm 0.2)$ obtained by Bhaskar et al., (2012) for the same genotype but different variety (Elakki Bale). In the same light, the values obtained for the three genotypes (AAA, AAB and ABB) are lower than those (7,6.2 and $8.1 \%$ ) obtained by Happi Emaga et al., (2007) for the banana peels of AAA (Large Dwarf), AAB (Big Ebanga) and ABB (pelipita) respectively. The TDF levels range from $10.23-50.09 \%$, and are higher in the banana group than in plantain. The highest values are observed in the AAA genotype (Lagun Vunalir) (Table 5 ). The value obtained for AAA is higher than that (4.96\%) obtained by Sheng et al., (2010). This could be due to the difference in variety observed within the same genomic group and also the ecological differences in the different areas of cultivation.

\section{Macromininerals and Microminerals composition}

The minerals are classified into two major groups: the macrominerals and microminerals (trace elements). The macrominerals composition expressed in $\mathrm{mg} / 100 \mathrm{~g}$, DW shows that potassium, calcium, phosphorus and magnesium were high (Table 6). Potassium (5016.6 - $6480 \mathrm{mg} / 100 \mathrm{~g} \mathrm{DW}$ ) was the most abundant macromineral in the bananas blossoms of the three genotypes, followed by calcium, magnesium and phosphorus. The results obtained for the three genotypes (AAA, AAB and $A B B$ ) are higher than those observed by Sheng et al., (2010) and Wickramarachchi and Ranamukhaarachchi, (2005). The AAA genotype had the highest calcium content while ABB had the lowest. Happi Emaga et al., (2007) have also shown that banana peels had a higher potassium content than calcium, phosphorus and magnesium.

Table 6: Macrominerals composition (mg/100g, DW)

\begin{tabular}{|c|c|c|c|c|c|}
\hline \multirow[t]{2}{*}{ Genotype } & \multicolumn{5}{|c|}{ Macrominerals } \\
\hline & $\mathrm{Ca}$ & $P$ & $\mathrm{Mg}$ & K & $\mathrm{Na}$ \\
\hline $\begin{array}{l}\text { AAA } \\
\text { AAB } \\
\text { ABB }\end{array}$ & $\begin{array}{l}687 \pm 0.00^{\mathrm{a}} \\
570 \pm 0.00^{\mathrm{b}} \\
482 \pm 0.00^{\mathrm{c}}\end{array}$ & $\begin{array}{l}211 \pm 0.00^{\mathrm{c}} \\
217 \pm 0.00^{\mathrm{b}} \\
296.6 \pm 0.00^{\mathrm{a}}\end{array}$ & $\begin{array}{l}273 \pm 0.00^{\mathrm{a}} \\
211.3 \pm 0.00^{\mathrm{c}} \\
232 \pm 0.00^{\mathrm{b}}\end{array}$ & $\begin{array}{l}6480 \pm 0.01^{\mathrm{a}} \\
5246.6 \pm 0.05^{\mathrm{b}} \\
5016.6 \pm 0.04^{\mathrm{c}}\end{array}$ & $\begin{array}{c}4.7 \pm 0.00^{\mathrm{c}} \\
6.4 \pm 0.00^{\mathrm{a}} \\
5.1 \pm 0.00^{\mathrm{b}}\end{array}$ \\
\hline
\end{tabular}

NB: Means with different letter superscripts on the same row are statistically different $(P<0.05)$. 
In the organism, phosphorus is closely related to calcium, for both contribute to the formation and the solidification of bones. Food is "good" if the $\mathrm{Ca} / \mathrm{P}$ ratio is at most equal to 0.5 . This increases the absorption of calcium in the small intestine (Olaofe et al., 2009). This ratio is higher than 0.5 (3.25 for AAA, 2.62 for
$A A B$ and 1.62 for $A B B$ ) in the banana blossoms suggesting rather, an average absorption of the calcium they contain. The consumption of these banana blossoms is to be encouraged calcium deficient individuals, even if they do not live in areas of great supply of bananas blossoms.

Table 7: Microminerals composition (mg/100g, DW)

\begin{tabular}{|l|l|l|l|c|}
\hline \hline \multirow{2}{*}{ Genotype } & \multicolumn{3}{|c|}{ Microminerals } \\
\cline { 2 - 5 } & & & & \\
& & $\mathrm{Zn}$ & $\mathrm{Cu}$ & $\mathrm{Mn}$ \\
\hline $\mathrm{AAA}$ & $158.13 \pm 1.84^{\mathrm{ac}}$ & $22.53 \pm 0.23^{\mathrm{a}}$ & $5.43 \pm 0.01^{\mathrm{a}}$ & $46.60 \pm 0.34^{\mathrm{a}}$ \\
$\mathrm{AAB}$ & $166.16 \pm 4.56^{\mathrm{a}}$ & $17.20 \pm 0.05^{\mathrm{c}}$ & $3.07 \pm 0.00^{\mathrm{b}}$ & $37.30 \pm 0.00^{\mathrm{b}}$ \\
ABB & $151.26 \pm 4.21^{\mathrm{c}}$ & $22.52 \pm 0.05^{\mathrm{a}}$ & $3.07 \pm 0.00^{\mathrm{b}}$ & $32.46 \pm 0.80^{\mathrm{c}}$ \\
\hline \hline
\end{tabular}

NB: Means with different letter superscripts on the same row are statistically different $(P<0.05)$.

The trace elements, in descending order of quantity, were $\mathrm{Fe}(151$ - 166.16), Mn (32 - 46.40), Zn (17 22.53) and $\mathrm{Cu}(3-5.43 \mathrm{mg} / 100 \mathrm{~g} \mathrm{DW})$. These values are lower for AAA genotype $(56.4 \mathrm{mg} / 100 \mathrm{~g} \mathrm{DW})$ and higher (ABB) than those $(0.01 \mathrm{mg} / 100 \mathrm{~g} \mathrm{DW})$ observed by Sheng et al., (2010) and Wickramarachchi and Ranamukhaarachchi, (2005). This may be due to differences in varieties and environmental factors. The biological roles of a number of trace elements have been reported. $\mathrm{Mn}$ and $\mathrm{Fe}$ are essential minerals for both plants and animals (Valkovic, 1978). Some of these minerals serve as prosthetic groups of some enzymes.

\section{CONCLUSION}

This study was carried out in order to determine the nutritional composition of blossoms of three varieties of bananas and plantains grown in Cameroon. The results show that banana blossoms have a high content of dietary fibre, mainly insoluble dietary fibre (IDF). They could therefore be used as a source of fibres in controlling obesity and diabetes. They could also be exploited to prepare higher added value products such as the lignocellulose fractions. They also have good levels of total carbohydrates and could therefore be used in the treatment of energetic deficiency or be utilized in Food technology to give foodstuffs a specific sensorial quality. All the genotypes have high levels of unsaturated fatty acids especially linoleic and gamma-linolenic acids; they could be exploited to avoid atherome formation that leads to arteriosclerosis. For minerals, potassium, calcium and iron are the most abundant; they could be used to sort out micronutrient deficiency knowing that the prevalence within 1-to-5 year children in Cameroon reaches $47.4 \%$. In some of the nutrients a significant difference was observed between the dessert banana $(A A A)$, cooking banana (ABB) and plantain (AAB) groups. These banana and plantain blossoms also have a good protein quality and could also be used in livestock feed formulations. From their nutritional composition, these banana blossoms could be classified as: Genotype AAA (Lagun Vunalir) >
Genotype AAB (Zip Ekon) > Genotype ABB (Pisang Kepok Bung). They are therefore not to be regarded as "waste", as is the current practice in Cameroon.

\section{ACKNOWLEDGMENTS}

The authors thank all the members of the Laboratory for Food Science and Metabolism (LabSAM), Department of Biochemistry, University of Yaoundé I. Special thanks go to KAMDA Aristide for his collaboration. The authors are also grateful to the Laboratory of Post Harvest Technology, CARBAP.

\section{REFERENCES}

AOAC (1980). Official Methods of Analysis. (13 ${ }^{\text {th }}$ ed.). William Horwitz, Washington,

D.C. Association of Official Analytical Chemists.

AFSSA (2009). Etude Individuelle Nationale des Consommations Alimentaires 2 (INCA2) 2006-2007. http://www.anses.fr/Documents/PASERRA-INCA 2.pdf, 228p. Consulted on $18^{\text {th }}$ November 2012.

AFSSA (2010). Avis de l'Agence Française de Sécurité Sanitaire des Aliments relatifs à l'actualisation des apports nutritionnels pour les acides gras. In AFSSASaisine 2006- SA-0359.

http://www.anses.fr/Documents/NUT2006sa0359.pdf, 10p. Consulted on $18^{\text {th }}$ November 2012.

Akubor PI and Ishiwu C (2013). Chemical composition, physical and sensory properties of cakes supplemented with plantain peel flour. International Journal of Agricultural Policy and Research, 1: 87-92.

Benton JJ and Vernon WC (1990). Sampling, handling and analyzing plant samples Westerman (ED) soil testing and plant analysis $\left(3^{\text {rd }}\right.$ ed). SSSA Book Series $N^{\circ} 3$, $784 \mathrm{p}$.

Bhaskar JJ, Salimath PV and Nandini CD (2011). Stimulation of glucose uptake by Musa sp. (cv. elakki bale) flower and pseudostem extracts in Ehrlich ascites tumor cells. Journal of Agricultural and Food Chemistry, 91: 1482-1487.

Bhaskar JJ, Mahadevamma S, Nandini D, Chilkunda and Salimath PV (2012). Banana (Musa sp. var. elakki bale) Flower and Pseudostem: Dietary Fiber and Associated Antioxidant Capacity. Journal of Agricultural and Food Chemistry, 60: 427-432. 
Dubois M, Gilles KA, Hamilton JK, Rebers PA and Smith $F(1956)$. Colorimetric Method for Determination of Sugars and Related Substances. Agricultural Research Service, 28p.

Dury S, Bricas N, Tchango Tchango J, Temple L and Bikoï A (2002). The determinants of urban plantain consumption in Cameroon. Food Quality and Preference, $13: 81-88$.

FAO (1970). Table de composition des aliments à l'usage de l'Afrique. Documents Nutrition. Rome, 3: 4 - 136.

FAO (1999). Statistic Series 52. Year book Production. Agriculture. Rome, Italy, 254p.

FAO/WHO (2001). Human vitamin and mineral requirements. Report of a joint FAO/WHO expert consultation Bangkok, Thailand, 281p.

FAO/WHO (2003). Diet, Nutrition and the Prevention of Chronic Diseases. WHO Technical Report Series 916, WHO, Geneva, 160p.

FAO/WHO (2007). Protein and amino acid requirements in human nutrition. WHO Technical Report Series 935, WHO, Geneva, 180p.

Gil A, Serra-Majem L, Calder PC and Uauy R (2012). Systematic reviews of the role of omega- 3 fatty acids in the prevention and treatment of disease. British Journal of Nutrition, 107: S1-S2.

Happi Emaga $\mathrm{T}$, Andrianaivo $\mathrm{RH}$, Wathelet $\mathrm{B}$, Tchango Tchango $\mathrm{J}$ and Paquot $\mathrm{M}$ (2007). Effects of the stage of maturation and varieties on the chemical composition of banana and plantain peels. Food Chemistry, 103: 590600.

Happi Emaga T, Robert C, Ronkart SN, Wathelet B and Paquot M (2008a). Dietary fibre components and pectin chemical features of peels during ripening in banana and plantain varieties. BioresourceTechnology, 99: 4346-4354.

Happi Emaga T, Ronkart SN, Robert C, Wathelet B and Paquot M (2008b). Characterisation of pectins extracted from banana peels (Musa AAA) under different conditions using an experimental design. Food Chemistry, 108: 463-471.

INIBAP (International Network for the Improvement of Banana and Plantain) (2002). Net Working Banana and Plantain: INIBAP Annual Report 2001, Montpelier, France.

IUPAC (International Union of Pure and Applied Chemistry) (2004). Standard methods for the analysis of oils, fats and derivatives. Oxford: Pergamon Press. 1990; Technology, 37: 657-661.

Kaiser FE, Gehrke ChW, Zumbalt RW, and Kuo KC (1974). Amino acid analysis. Hydrolysis, ion-exchange clean-up, derivatisation and quantitation by gas-liquid chromatography. Journal of Chromatography , 94: 113133.

Kanazawa K and Sakakibara H (2000). High content of dopamine, a strong antioxidant, in Cavendish banana.
Journal of Agricultural and Food Chemistry, 48: 844848.

Kouassi KS (2001). La création variétale par pollinisation manuelle chez les bananiers (Musa spp.). Mémoire DEA. Université d'Abidjan-Cocody, Côte d'Ivoire, 50p.

Lassoudière A (2007). Le bananier et sa culture. Versailles, France. Edition Quæ, 384p.

Mohapatra D, Sabyasachi M and Namraba S (2010). Banana and its by-products utilization: An overview. Journal of Scientific and Industrial Research, 69: 323329.

Murphy $J$ et Riley JP (1962). A modified single solution method for phosphate in waters Analytica Chimica Acta, 27: 31-36.

Olaofe O, Faleye FJ, Adeniji AA and Akinsola AF (2009). Amino acid and mineral compositions and proximate analysis of Chinese bottle, Lagenaria siceraria. Electronic Journal of Environmental, Agricultural and Food Chemistry, 8: 534-543.

Pari L and Maheshwari UJ (2000). Antihyperglycemic activity of Musa sapientum flowers: Effect on lipid peroxidation in alloxan diabetic rats. Phytother Ressources,14:136-138.

Pasupuleti V and Anderson W (2008). Book on "Nutraceuticals, Glycemic Health and Type 2 Diabetes", Ames, IA: Wiley-Blackwell Publishers, 20p.

Prosky L, Asp NG, Schweizer TF, De Vries JW and Furda I (1992). Determination of insoluble and soluble dietary fiber in foods and food products: Collaborative study. Journal of Association of Official Analytical Chemist, 75: 360-367.

Ramadan MF, and Mörsel JF (2002). Neutral lipids classes of blackcumin (Nigella sativa L.) seed oils. European Food Research and Technology, 214: 202-206.

Robinso JC (1996). Distribution and importance; taxonomic classification, cultivars and breeding. In: J. C. Robinson (Ed.), Banana and plantains (p. 1-33). Wallingford: CAB International.

Schneeman BO (1987). Soluble and insoluble fiber-different physiological response. Food Technology, $2: 81-82$.

Sheng ZW, Wei-Hong M, Jin-He G, Yang B, Wei-Min Z, HuaTing D and Zhi-Qiang $J(2010)$. Investigation of dietary fiber, protein, vitamin $\mathrm{E}$ and other nutritional compounds of banana flower of two cultivars grown in China. African Journal of Biotechnology, 9: 3888-3895.

Someya S, Yoshiki Y and Okubo K (2002). Antioxidant compounds from bananas (Musa Cavendish). Food Chemistry, 79: 351-354.

Stover RH and Simmonds NW (1987). Classification of banana cultivars. In R. H. Stover \& N. W. Simmonds (Eds.), Bananas (3rd ed., pp. 97-103). New York: Wiley.

Wickramarachchi KS and Ranamukhaarachchi SL (2005). Preservation of Fiber-Rich Banana Blossom as a Dehydrated Vegetable. Science Asia, 31: 265-271.

Cite this Article: Awedem Wobiwo F, Achu Mercy BL and Happi Emaga T, (2015). Nutritive Value of three varieties of banana and plantain blossoms from Cameroon. Greener Journal of Agricultural Sciences, 5(2): 52-61, http://doi.org/10.15580/GJAS.2015.2.012115009. 